choices similar to those in AIDS or Visna viruses. The pattern of preferred codons varies in and between different gene families ${ }^{1-4}$; the widest variation observed so far is with immune system genes, in which even the constant and variable segments of the same immunoglobulin mRNA differ in this respect ${ }^{9}$. We believe that, in the context of a study of coevolution of viruses and the immune system, an interesting comparison for AIDS/ Visna virus coding strategy is that of different members of the threatened defense system. We find that some T-cell receptor coding sequences share triplet preferences with AIDS/Visna viruses, although the results remain difficult to interpret.

R. Grantham

Institut d'Evolution Moléculaire, P.PERRIN

Université Lyon I, 69622 Villeurbanne, France

1. Grantham. R. et al. Nucleic Acids Res. 8, r49-r62 (1980).

2. Grantham, R. Trends biochem. Sci. 5, 327-331 (1980)

3. Grantham, R. et al. Nucleic Acids Res. 9, r43-r74 (1981); Bull. Inst. Pasteur 83. 95-148 (1985).

4. Grantham, R. et al. Oxford Surveys in Evolutionary Biology $\mathbf{3}$ (in the press).

5. Ratner, L. et al. Nature 313, 277 - 284 (1985).

6. GenBank release $35(1985)$.

7. Sonigo, P. et al. Cell 42,369-382 (1985).

8. Chiu, I.M. et al. Nature 317, 366-368 (1985)

9. Perrin, P. Nucleic Acids Res. 12, 5515-5527 (1984)

\section{Origin of the human} AIDS virus

SIR-Recent reports ${ }^{1-3}$ as well as recent correspondence to Nature ${ }^{4}$ have dealt with the possible animal origins of the human AIDS (acquired immune deficiency syndrome) virus. I would like to consider other theories in addition to cross-species transmission for the origin of human $\mathrm{T}$ lymphotropic virus type III/lymphadenopathy-associated virus (HTLVIII/LAV).

One theory holds that HTLV-III/LAV has long been present in humans but confined to a small number of populations. Changing migration patterns (for example from rural to urban Africa) coupled with some practices of modern society (intravenous drug abuse and large numbers of homosexual partners) may have produced sufficient infection with HTLVIII/LAV to make AIDS a noticeable disease. The poor transmissibility of HTLVIII/LAV is consistent with this theory.

A second theory holds that HTLV-III/ LAV is a new variant of a retrovirus that has always infected mankind. There are a number of human diseases for which a viral aetiology is as yet only suspected or for which the causative viral agent has not yet been identified. These include non- $A$ non-B hepatitis, multiple sclerosis and rheumatoid arthritis. Some of the features of these diseases resemble those of lentivirus-induced disease. HTLV-III/ LAV could conceivably be a new, T-cell tropic variant of a previously unidentified human lentivirus.
The recent isolation of a HTLV-III/ LAV-related simian virus (called STLVIII) first from macaques ${ }^{5}$ and then from African green monkeys ${ }^{6}$ has raised speculation regarding a third theory - that HTLV-III/LAV is a human-adapted virus arising from cross-species transmission from monkeys. Such cross-species transmissions have been documented, although rarely, in virology. The most recent occurrence is the appearance of canine parvovirus as a new dog-adapted virus in $1978^{7.8}$. However, the mere existence of HTLV-III/LAV-related viruses in monkeys provides no evidence for crossspecies transmission to humans. In fact, the low degree of sequence conservation between HTLV-III/LAV and STLV-III $(<75 \%)$ argues against the transmission of one of these monkey viruses to humans relatively recently in history. Such sequence divergence has certainly not occurred after cross-species transmission of feline pan-leukopenia virus to dogs?

In the absence of a clear-cut candidate for cross-species transmission, we can expect arguments on the origin of the human AIDS virus to continue.

Harvard Medical School, New England Regional Primate

Research Center,

Southborough,

Massachusetts 01772, USA

1. Kanki, P. et al Lancet i, 1330-1332 (1985).

2. Wong-Staal, F. \& Gallo, R. Nature 317, 395-403 (1985).

3. Norman, C. Science 230, 1140-1142 (1985).

4. Rosenoir, J. Nature 317, 100 (1985).

4. Rosenoir, J. Nature 317, 100 (1985).
5. Daniel, M.D. et al. Science 228, 1201-1204 (1985).

6. Kanki, P. et al. Science 230, 951-954 (1985).

7. Tratschin et al. J. gen Virol. 61, $33-41$ (1985)

8. Parrish et al. Science 230, 1046-1049 (1985).

\section{The occurrence of reversible epithelia}

SIR-A recent letter to Nature ${ }^{1}$ described an interesting case of an epithelium, the morphological and functional polarity of which can be reversed experimentally. The accompanying News and Views article $^{2}$ described it as "a curious violation of the usual rules" that "offers a promising system for learning how epithelia become programmed during development".

In fact, this case is a representative example of what is likely to be a general property of epithelia. Morphological and functional reversal of epithelial polarity was first discovered by Mauchamp and his colleagues using thyroid follicles more than 10 years ago ${ }^{3.4}$ and studied further by Nitsch and Wollman ${ }^{5}$. Since then, a vast body of literature has accumulated about similar phenomena in other systems; to name but a few examples, the gut of the sea urchin embryo ${ }^{6}$, retinal pigmented epithelium ${ }^{7}$ and the epiblast of the early chick embryo ${ }^{8}$. The stimulus for reversal can be anything that produces an asymmetric environment across the tissue, includ- ing $p \mathrm{H}$, serum concentration, cell contact, salt concentration and electrical potential. The mechanism of reversal has received most detailed attention from Jaffe".

It seems to me that the above systems, in which epithelial polarity can be manipulated experimentally using embryonic tissues, might be more suitable for studying the relevance of this phenomenon to embryonic development than the more recent case ${ }^{1.2}$.

C. D. STERN

Department of Human Anatomy,

South Parks Road,

Oxford $O X 13 Q X, U K$

1. Schwartz, G.J., Barasch, J. \& Al-Awqati. Q. Nature 318. (1985)

2. Diamond, J.M. Nature 318, 311 (1985)

. Mauchamp. J. \& Fayet. G. Endocr. exp. 8. 170 (1974).

4. Mauchamp. J. et al. Cell Tissue Res. 204.417 (1979).

Nitsch, L. \& Wollman. S.H. J. Cell Biol. 86. 875 (1980).

6. Amemiya, S. et al. J.exp. Zool. 210, 177 (1979)

7. Crawford, B.J. Tissue Cell 15. 993 (1983).

8. Stern, C.D. \& MacKenzie, D.O.J. Embryol. exp. Morph. 77, 73 (1983)

9. Jaffe, L.F. Phil. Trans. R. Soc. B 295, 553 (1981).

\section{Phenolic degradation by "dissimilatory plasmid"}

SIR-We have been studying the degradation of phenolic substances by bacteria and we have examined the various terms used by investigators to designate the plasmids associated with their degradation. They have been termed "degradative plasmids"', "catabolic plasmids" and "metabolic plasmids"3.4.

The term "degradation" suggests the immediate product formation (transformation of the substrate) whereas dissimilation would mean the complete cleavage of a substrate leading to its utilization as an energy source. Most of the reports indicate the complete or near complete dissimilation of aromatic substances. Therefore in our opinion, the expression "dissimilatory plasmid" is more indicative of the functional role of the plasmid than the other terms suggested.

S. Balajee,

K. BOOMINATHAN

A. Mahadevan

Centre for Advanced Study in Botany,

University of Madras,

Madras-600 025, India

1. Chakrabarthy, A.M. Proc. natn. Acad. Sci. 70, 1641-16+4 (1973)

2. Williams. P.A. Trends biochem Sci. 6. 23-26 (1981).

Wong. C.L. \& Dunn. N.W. Genet. Res. Camb. 27, 405-412 (1976).

. Gunsalus, I.C. \& Yen. K.M. in Molecular Biology: Pathogenicity and Ecology of Bacterial Plasmids (eds Levev. S.B. et al.) 499-509 (Penum. New York. 1981).

\section{Scientific Correspondence}

Scientific Correspondence is intended to provide a forum in which readers may raise points of a rather technical character which are not provoked by articles or letters previously published (where the Matters Arising section remains appropriate). 